\title{
POLA KONSUMSI LEMAK DAN RLPP BERHUBUNGAN DENGAN KEJADIAN PENYAKIT JANTUNG KORONER
}

\author{
Igha Aprilesika Pabela, Arie Krisnasary, Miratul Haya \\ Politeknik Kesehatan Kementerian Kesehatan Bengkulu, Program Studi D-IV Gizi \\ Jalan Indragiri Nomor 03 Padang Harapan Kota Bengkulu \\ Ighapabela38@gmail.com
}

\begin{abstract}
Heart and blood vessel disease is a disorder that occurs in the heart organ as a result of functional, anatomical and hemodynamic disorders. The purpose of research to know the relationship of fat pattern (saturated and unsaturated) and RLPP with the incidence of coronary heart disease in outpatient poly RSUD M. Yunus City Bengkulu Year 2017.This research is an analytical survey with retrospective approach, case control design. Research location in outpatient clinic of RSUD M. Yunus Kota Bengkulu. The study was conducted on May 8-June 8, 2017. The sample was PJK patients treated in outpatient clinic RSUD M. Yunus of Bengkulu City as many as 74 samples. Done by purposive sampling technique. Data of intake of saturated fat and unsaturated patients obtained form food frequency questioner (FFQ) and data RLPP, age, gender, blood pressure smoking habit was obtained through questionnaire. Data were analyzed using univariate and bivariate. Almost all patients often consume saturated and unsaturated fats. Almost all patients with RLPPP have nutritional status of obesity. There was a significant relationship between fat consumption pattern (saturated and unsaturated), RLPP, gender, smoking habit with incidence of coronary heart disease. There is a relationship between fat consumption pattern (saturated and unsaturated), RLPP with the incidence of coronary heart disease in outpatient RSUD M. yunus of Bengkulu City in 2017. the need for active family role related to motivation by reminding the eating pattern of coronary heart disease patients.
\end{abstract}

Keywords: RLPP, Coronary Heart Disease, the pattern consumption of saturated fat and unsaturated fat.

\begin{abstract}
Abstrak: Penyakit jantung dan pembuluh darah merupakan suatu kelainan yang terjadi pada organ jantung dengan akibat terjadinya gangguan fungsional, anatomis serta sistem hemodinamis.Tujuan penelitian untuk mengetahui hubungan pola konsumsi lemak (jenuh dan tak jenuh) dan RLPP dengan kejadian penyakit jantung koroner di poli rawat jalan RSUD M. Yunus Kota Bengkulu Tahun 2017.Penelitian ini merupakan survey analitik dengan pendekatan retrospective, desain case control.Lokasi penelitian di poli rawat jalan RSUD M. Yunus kota Bengkulu. Penelitian dilaksanakan tanggal 8 Mei -8 Juni 2016. Sampel adalah pasien PJK yang berobat di poli rawat jalan RSUD M. Yunus Kota Bengkulusebanyak 74 sampel.dilakukan dengan teknik purposive sampling. Data asupan lemak jenuh dan tak jenuh pasien, diperoleh melalui form food frequency questioner (FFQ) dan data RLPP, usia, jenis kelamin, tekanan darah, kebiasaan merokok diperoleh melalui kuesioner. Data yang diperoleh dianalisis menggunakan univariat dan bivariat.Hampir seluruh pasien sering mengkonsumsi lemak jenuh dan tak jenuh.Hampir seluruh pasien dengan RLPP berstatus gizi obesitas. Ada hubungan yang signifikan antara pola konsumsi lemak (jenuh dan tak jenuh), RLPP, jenis kelamin, kebiasaan merokok dengan kejadian penyakit jantung koroner. Tidak ada hubungan antara usia dan tekanan darah dengan kejadian penyakit jantung koroner.Ada hubungan antara pola konsumsi lemak (jenuh dan tak jenuh), RLPP dengan kejadian penyakit jantung koroner di poli rawat jalan RSUD M. Yunus Kota Bengkulu Tahun 2017. Perlunya peran aktif keluarga terkait motivasi dengan cara mengingatkan pola makan pasien penyakit jantung koroner.
\end{abstract}

Kata Kunci : RLPP, Penyakit Jantung Koroner, Pola Konsumsi Lemak Jenuh dan Tak Jenuh. 
Penyakit jantung dan pembuluh darah merupakan suatu kelainan yang terjadi pada organ jantung dengan akibat terjadinya gangguan fungsional, anatomis serta sistem hemodinamis. Penyakit jantung koroner menggambarkan suatu penyakit yang berat, dengan mortalitas tinggi serta merupakan suatu keadaan gawat darurat jantung dengan manifestasi klinis berupa keluhan perasaan tidak enak atau nyeri dada yang disertai dengan gejala lain sebagai akibat iskemia miokard (Depkes RI, 2007).

Penyakit jantung koroner disebabkan oleh penumpukan lemak pada dinding pembuluh darah jantung, diikuti oleh berbagai proses seperti penimbunan jaringan ikat, pembekuan darah yang akan mempersempit atau menyumbat pembuluh darah tersebut dan mengakibatkan otot jantung di daerah tersebut mengalami kekurangan aliran darah. Hal ini menimbulkan berbagai akibat yang cukup serius, mulai dari nyeri dada (angina pektoris) sampai serangan jantung (infark jantung) yang dapat menyebabkan kematian mendadak (CDC , 2009).

Peningkatan lemak dalam perut akan menyebabkan kelainan metabolisme lipid. Kelainan fraksi lipid yang utama adalah kenaikan kadar kolesterol total, kenaikan Low Density Lipoprotein (LDL), kenaikan kadar trigliserida, dan penurunan kadar kolesterol High Density Lipoprotein (HDL) (Riska, 2008).
Lemak dalam rongga perut merupakan salah satu pemicu terjadinya penyakit kardiovaskuler salah satunya hiperkolesterolemia yang dapat diketahui dari hasil pengkukuran lingkar pinggang pinggul.Sehingga Rasio Lingkar Pinggang Pinggul (RLPP) dapat menunjukkan hiperkolesterolemia dan penyakit kardiovaskuler (Riska, 2008).

Tujuan penelitian ini untuk mengetahui hubungan pola konsumsi lemak (jenuh dan tak jenuh) dan RLPP dengan kejadian penyakit jantung koroner di poli rawat jalan RSUD M. Yunus Bengkulu.

\section{BAHAN DAN CARA KERJA}

Desain penelitian ini adalah case control.Penelitian ini dilaksanakan pada tanggal 8 Mei sampai 8 Juni 2017. Penelitian dilakukan di poli rawat jalan bagian jantung RSUD M.Yunus Bengkulu.Jumlah sampel dalam penelitian ini sebanyak 74 sampel dengan carapengambilan sampel menggunakan teknik purposive samplingdengan kriteria inklusi.Data primer terlebih meliputi, identitas pasien, tekanan darah, kebiasaan merokok, dan data penunjang lainnya yang diperoleh anamnesa, wawancara dan observasi kepada pasien dan keluarganya secara langsung. Dataantropometri pasien diperoleh dengan melakukan pengukuran langsung kepada pasien. 
Data faktor pola konsumsi lemak (jenuh dan tak jenuh), RLPP, usia, jenis kelamin, tekanan darah, dan kebiasaan merokok yang telah terkumpul selanjutnya diolah dan dianalisis.Uji statistik yang digunakan adalah analisis univariat variabel yang diteliti menggunakan distribusi frekuensi dan analisis bivariat.Analisis bivariat bertujuan untuk mengetahui hubungan antara variabel independen pola konsumsi lemak (jenuh dan tak jenuh), RLPP, usia, jenis kelamin, tekanan darah, dan kebiasaan merokok dengan variabel dependen kejadian penyakit jantung koroner yang masing-masing variabelberskala nominal menggunakan uji chi-square

\section{HASIL}

\section{Analisa Univariat}

Tabel 1. Gambaran Pola Konsumsi Lemak, RLPP, Usia, Jenis Kelamin, Tekanan Darah, dan Kebiasaan Merokok di Poli Rawat Jalan RSUD M. Yunus Kota Bengkulu Tahun 2017

\begin{tabular}{lcc}
\hline \multicolumn{1}{c}{ Variabel } & N & \% \\
\hline \multicolumn{2}{l}{ Pola Konsumsi Lemak Jenuh } & \\
Jarang & 11 & 14,9 \\
Sering & 63 & 85,1 \\
Pola Konsumsi Lemak Tak Jenuh & \\
Jarang & 11 & 14,9 \\
Sering & 63 & 85,1 \\
RLPP & & \\
Tidak Obesitas & 10 & 13,5 \\
Obesitas & 64 & 86,5 \\
Usia & & \\
< 45 tahun & 8 & 10,8 \\
$\geq 45$ tahun & 66 & 89,2 \\
JenisKelamin & & \\
Perempuan & 22 & 29,3 \\
Laki-laki & 52 & 70,3 \\
Tekanan Darah & & \\
Normal & 40 & 54,1 \\
Tidak Normal & 34 & 45,9 \\
\hline
\end{tabular}

\begin{tabular}{lll}
\hline Kebiasaan Merokok & & \\
& & \\
Tidak Merokok & 24 & 32,4 \\
Merokok & 50 & 67,6 \\
\hline
\end{tabular}

Berdasarkan tabel 1. hampir seluruh pasien PJK yang berobat di poli jantung RSUD M. Yunus sering mengkonsumsi lemak jenuh maupun lemak tak jenuh sebanyak 63 orang $(85,1 \%)$. RLPP hampir seluruh pasien mengalami obesitas atau penumpukan lemak di perut sebanyak 64 orang (86,5\%). Hampir seluruh pasien PJKberusia 45 tahun keatas $(89,2 \%)$ sebanyak 66 orang. Sebagian besar pasien berjenis kelamin laki-laki sebanyak 52 orang $(70,3 \%)$. Tekanan darah sebagian pasien cenderung normal yaitu sebesar $(54,1 \%) 40$ orang. Sebagian besar pasien memiliki kebiasaan merokok sebanyak 50 orang $(67,6 \%)$

\section{Analisa Bivariat Hubungan RLPP dengan Kejadian Penyakit Jantung Koroner di Poli Rawat Jalan RSUD M. Yunus Bengkulu}

Tabel 2. Hubungan RLPP dengan Kejadian Penyakit Jantung Koroner di Poli Rawat Jalan RSUD M. Yunus Kota Bengkulu Tahun 2017

\begin{tabular}{|c|c|c|c|c|c|c|c|c|}
\hline \multirow[t]{3}{*}{ RLPP } & \multicolumn{4}{|c|}{ Kejadian PJK } & \multirow{2}{*}{$\begin{array}{l}\text { To } \\
\text { tal }\end{array}$} & & \multirow[b]{2}{*}{ p } & \multirow{2}{*}{$\begin{array}{c}\text { OR } \\
(95 \\
\% \\
\text { CI) }\end{array}$} \\
\hline & \multicolumn{2}{|c|}{ PJK } & \multicolumn{2}{|c|}{$\begin{array}{l}\text { Tidak } \\
\text { PJK }\end{array}$} & & & & \\
\hline & $n$ & $\%$ & $\mathbf{N}$ & $\%$ & $n$ & $\%$ & & \\
\hline Obesit & 3 & 97 & 28 & 75 & 64 & 86 & & \\
\hline as & 6 &, 3 & &, 7 & &, 5 & 0 & 11,2 \\
\hline Tidak & 1 & 2 & 9 & 24 & 10 & 13 & 01 & 5 \\
\hline $\begin{array}{l}\text { Obesit } \\
\text { as }\end{array}$ & & 7 & & ,3 & &, 5 & 4 & $\begin{array}{c}(1,3 \\
8-\end{array}$ \\
\hline Total & 3 & 10 & 37 & 10 & 74 & 10 & & 96,8 \\
\hline & 7 & 0 & & 0 & & 0 & & 0) \\
\hline
\end{tabular}

Berdasarkan tabel 2 pada kelompok kasus hampir seluruh $(97,3 \%)$ dengan RLPP obesitas, demikian juga pada kelompok 
kontrol sebagian besar $(75,7 \%)$ dengan RLPP obesitas. Berdasarkan hasil uji statistik diperoleh bahwanilai $\mathrm{p}=0,014$. Hal ini menunjukan bahwa ada hubungan yang signifikan antara RLPP dengan kejadian PJK di poli rawat jalan RSUD M. Yunus Kota Bengkulu Tahun 2017. Berdasarkan nilai OR 11,25 artinya seorang yang berstatus gizi obesitas berisiko 11,25 kali terserang penyakit jantung koroner daripada pasien yang berstatus gizi normal.

Hubungan Pola Konsumsi Lemak Jenuh dengan Kejadian Penyakit Jantung Koroner di Poli Rawat Jalan RSUD M. Yunus Kota Bengkulu Tahun 2017

Tabel 3. Hubungan Pola Konsumsi Lemak Jenuh dengan Kejadian Penyakit Jantung Koroner di Poli Rawat Jalan RSUD M. Yunus Kota Bengkulu Tahun 2017

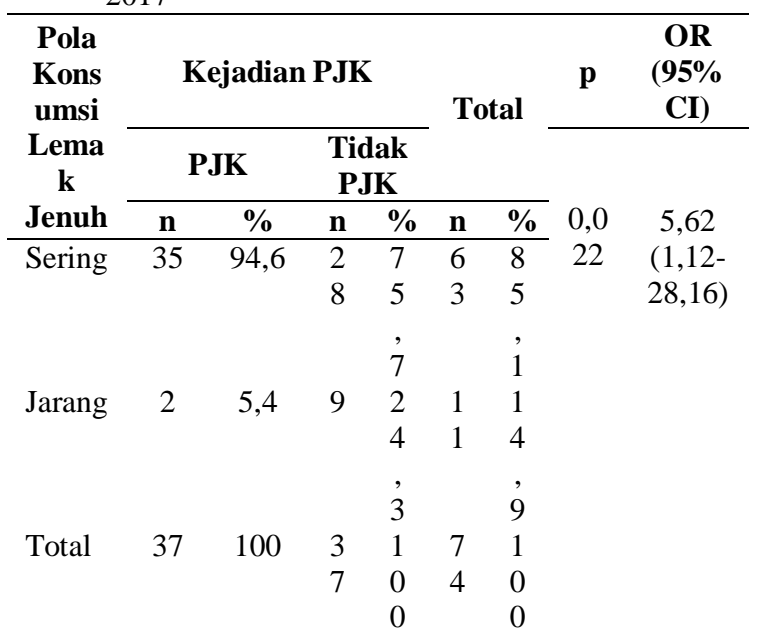

Berdasarkan tabel 3. pada kelompok kasus hampir seluruh $(94,6 \%) \quad$ sering mengkonsumsi lemak jenuh, demikian pada kelompok kontrol sebagian besar $(75,7 \%)$ sering mengkonsumsi lemak jenuh. Berdasarkan hasil uji statistik diperoleh bahwa nilai $\mathrm{p}=0,022$. Hal ini menunjukan bahwa ada hubunganyang signifikan antara pola konsumsi lemak dengan kejadian PJK di poli rawat jalan RSUD M. Yunus Kota Bengkulu Tahun 2017. Berdasarkan nilai OR 5,62 artinya seorang yang sering mengkonsumsi lemak jenuh berisiko 5,62 kali terserang penyakit jantung koroner daripada pasien yang jarang mengkonsumsi lemak jenuh.

Hubungan Pola Konsumsi Lemak Tak Jenuh dengan Kejadian Penyakit Jantung Koroner

Tabel 4. Hubungan Pola Konsumsi Lemak Tak Jenuh dengan Kejadian Penyakit Jantung Koroner di Poli Rawat Jalan RSUD M. Yunus Kota Bengkulu Tahun 2017

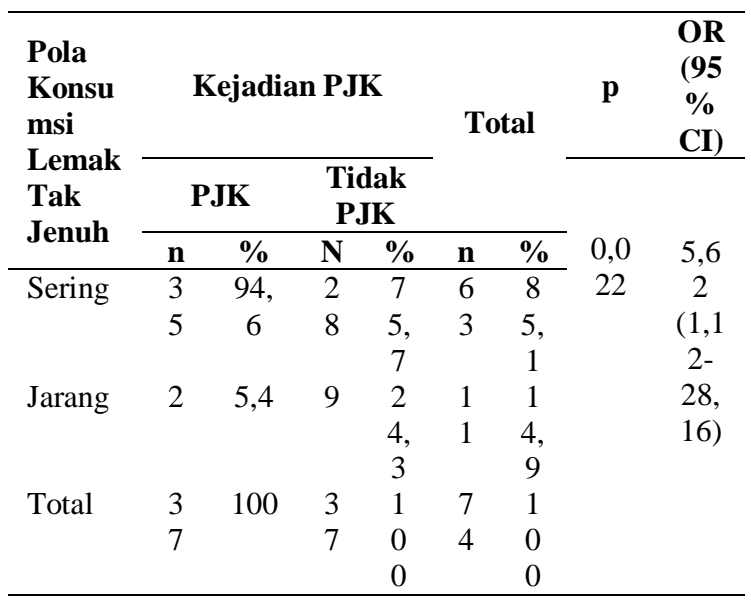

Berdasarkan table 4 pada kelompok kasus hampir seluruh $(94,6 \%)$ sering mengkonsumsi lemak tak jenuh, demikian pada kelompok kontrol sebagian besar $(75,7 \%)$ sering mengkonsumsi lemak tak jenuh. Berdasarkan hasil uji statistik diketahui bahwa nilai $\mathrm{p}=0,022$.Hal ini menunjukan bahwa ada hubungan yang signifikan antara pola konsumsi lemak tak jenuh dengan kejadian PJK di poli rawat jalan RSUD M. Yunus Kota Bengkulu 
Tahun 2017. Berdasarkan nilai OR dapat diketahui pasien yang sering mengkonsumsi lemak tak jenuh memiliki peluang 5,62 kali terserang penyakit jantung koroner.

\section{PEMBAHASAN}

Hubungan Pola Konsumsi Lemak Jenuh dengan Kejadian Penyakit Jantung Koroner

Hasil penelitian ini menunjukkan bahwa ada hubungan yang signifikan antara pola konsumsi lemak dengan kejadian penyakit jantung koroner pada pasien di poli rawat jalan RSUD M. Yunus Kota Bengkulu. Berdasarkan hasil wawancara menggunakan form food frequency questioner (FFQ), sebagian besar pasien sering mengkonsumsi lemak jenuh dengan frekuensi $\geq 4-6 x /$ minggu seperti santan kental, gorengan, kuning telur, udang, yang mengandung kolesterol sebanyak 63 orang atau $(85,1 \%)$.

Kolesterol berperan dalam proses aterosklerosis sehingga meningkatkan risiko serangan jantung dan stroke. Hal tersebut dikarenakan kolesterol menekan aktifitas protein yang memproteksi jantung dan pembuluh darah.Kolesterol membatasi aktivasi protein protektif TGF-beta (transforming growth factor beta)sehingga mengalami upregulated pada plak aterosklerosis manusia (Jung, 2010).

Hal ini sependapat dengan teori menyatakan bahwa konsumsi lemak terutama asam lemak jenuh, akan berpengaruh terhadap kadar LDL yang menyebabkan darah mudah menggumpal, selain itu asam lemak jenuh mampu merusak dinding pembuluh darah arteri sehingga menyebabkan penyempitan (Yusuf dkk, 2013).

Berdasarkan teori asupan lemak jenuh dengan kadar kolesterol HDL pada kejadian penyakit jantung koroner terdapat hubungan dengan mekanisme asupan asam lemak jenuh mempengaruhi penurunan kadar kolesterol HDL dengan cara menghambat kerja enzim LCAT dari jaringan dan menurunkan faktor pembentukan kolesterol HDL yaitu Apoliprotein A-1. Apolipoprotein A-1 yang menurun akan mengakibatkan pembentukan kolesterol HDL menjadi terhambat. Sejalan dengan penelitian yang dilakukan Sulastri (2005) menyebutkan bahwa terdapat hubungan yang signifikan dan konsisten antara asupan lemak jenuh dengan kadar kolesterol HDL pada kejadian penyakit jantung koroner.

Sejalan dengan studi epidemiologi membuktikan bahwa terdapat hubungan positif yang bermakna antara konsumsi lemak, asam lemak jenuh menyebabkan hiperkolesterol yang merupakan faktor risiko dari PJK (Hardinsyah, 2011).

Asam lemak jenuh adalah asam lemak yang tidak memiliki ikatan rangkap pada atom karbon. Ini berarti asam lemak jenuh tidak peka terhadap oksidasi dan 
pembentukan radikal bebas seperti halnya asam lemak tidak jenuh, efek dominan dari asam lemak jenuh adalah peningkatan kadar kolesterol total dan K-LDL (kolesterol LDL) (Muller dkk, 2010).

Asam lemak jenuh mempunyai rantai karbon yang lebih pendek, densitas energinya lebih kecil, sehingga setiap gram asam lemak jenuh kandungan energinya lebih rendah.Di dalam hati hampir semua asam lemak teroksidasi menjadi energi dan energi yang dihasilkan langsung digunakan untuk meningkatkan pembakaran seluler dan mengaktifkan fungsi semua kelenjar endokrin, organ tubuh dan jaringan tubuh.Oleh karena itu banyaknya asam lemak rantai sedang yang disimpan dalam jaringan, sehingga tidak menimbulkan penumpukan lemak dalam tubuh (Bintahah, 2008).

Sejalan dengan penelitian Tuminah (2009) menyebutkan bahwa pola makan seperti konsumsi makanan yang tinggi lemak total atau lemak jenuh, kolesterol, serta kurangnya konsumsi karbohidrat merupakan faktor yang mempengaruhi kadar HDL dan merupakan faktor risiko PJK.

Hubungan Pola Konsumsi Lemak Tak Jenuh dengan Kejadian Penyakit Jantung Koroner

Hasil penelitian ini menunjukkan bahwa ada hubungan yang signifikan antara pola konsumsi lemak dengan kejadian penyakit jantung koroner pada responden di poli rawat jalan RSUD M. Yunus Kota Bengkulu. Berdasarkan hasil wawancara menggunakan form food frequency questioner (FFQ), sebagian besar pasien sering mengkonsumsi lemak tak jenuh dengan frekuensi $\geq 4-6 x /$ minggu seperti ikan mujahir, lele, nila, dan ikan laut, serta alpukat sebanyak 63 orang atau $(85,1 \%)$.

Asam lemak tak jenuh tunggal merupakan jenis asam lemak yang mempunyai satu ikatan rangkap pada rantai atom karbon.Asam lemak ini tergolong dalam asam lemak rantai panjang (LCFA), yang kebanyakan ditemukan dalam minyak zaitun, minyak kedelai, minyak kacang tanah, minyak biji kapas, dan kanola.Minyak zaitun adalah salah satu contoh yang mengandung MUFA 77\% (Ketaren, 2009).

Hal ini sejalan dengan penelitian menunjukkan bahwa asupan lemak tak jenuh yang tinggi dapat menurunkan kadar kolesterol dalam darah (Tuminah, 2009).

Secara umum lemak tak jenuh tunggal berpengaruh menguntungkan kadar kolesterol dalam darah, terutama bila digunakan sebagai pengganti asam lemak jenuh. asam lemak tak jenuh tunggal (MUFA) lebih efektif menurunkan kadar kolesterol darah, daripada asam lemak tak jenuh jamak (PUFA) (Almatsier, 2010).

Salah satu jenis MUFA adalah Omega 9 (oleat) memiliki sifat lebih stabil 
dan lebih baik perannya dibandingkan PUFA (asam lemak tak jenuh jamak.PUFA dapat menurunkan kolesterol LDL dan meningkatkan HDL.Penelitian yang dilakukan oleh Wood, menyatakan bahwa MUFA dapat menurunkan LDL dan meningkatkn HDL secara lebih besar daripada Omega 3 dan Omega 6. Substitusi lemak jenuh (S) dengan lemak tak jenuh jamak (P) dan emak tak jenuh tunggal (M) dapat menurunkan kadar kolesterol baik jumlah kolesterol total ataupun kolesterol LDL. Penurunan rasio LDL atau HDL akan menghambat terjadinya aterosklerosis (Muller, 2010).

\section{Hubungan RLPP dengan Kejadian Penyakit Jantung Koroner}

Berdasarkan hasil penelitian menunjukkan bahwa ada hubungan yang signifikan antara RLPP dengan kejadian penyakit jantung koroner di poli rawat jalan RSUD M. Yunus Kota Bengkulu. Dari hasil penelitian yang dilakukan hampir seluruh pasien PJK berdasarkan pengukuran RLPP memiliki status gizi obesitas yang lebih banyak ditemukan oleh pasien berjenis kelamin laki-laki sebanyak $(89,18 \%)$. Demikian pula sebagian besar pasien tidak PJK berdasarkan pengukuran RLPP memiliki status gizi obesitas yang lebih banyak ditemukan oleh pasien berjenis kelamin laki-laki sebanyak $(48,6 \%)$.
Peningkatan lemak dalam perut akan menyebabkan kelainan metabolisme lipid. Kelainan fraksi lipid yang utama adalah kenaikan kadar kolesterol total, kenaikan LDL, penurunan HDL. Lemak dalam rongga perut merupakan salah satu pemicu terjadinya penyakit kardiovaskuler salah satunya hiperkolesterolemia (Riska, 2008).

RLPP yang tidak normal akan meningkatkan risiko 2,64 kali meningkatkan kadar LDL dalam darah, yang berisiko terjadinya jantung koroner. Kolesterol LDL lebih popular dikenal sebagai kolesterol jahat.Berbagai penelitian, baik pada hewan, uji klinis dan penelitian epidemiologis menunjukkan bahwa hiperkolesterol LDL merupakan faktor risiko utama penyakit jantung koroner.Kolesterol LDL menyebabkan pengapuran pembuluh koroner dan menimbun kolesterol di pembuluh koroner (Ari, 2007).

Penelitian ini sejalan dengan yang dilakukan oleh Wiyono dkk, 2008 menunjukkan bahwa terdapat hubungan antara rasio lingkar pinggang pinggul dengan kadar kolesterol total, high density lipoprotein dan low density lipoprotein pada orang dewasa.Obesitas sangat dekat kaitanya dengan penyakit degeneratif seperti penyakit jantung koroner, hipertensi dan diabetes mellitus. Penumpukan lemak diperut (abdominal obesity) mempunyai 
pengaruh pada peningkatan tekanan darah, LDL, kolesterol, trigliserida dan gula darah serta menurunkan kadar HDL kolesterol (Sunarti dkk, 2013).

Rasio lingkar pinggang dan pinggul sebagai indikator adanya penimbunan lemak dalam perut yang dikenal dengan obesitas sentral atau obesitas visceral.Obesitas visceral menurut beberapa penelitian terbukti lebih berkaitan dengan kejadian beberapa penyakit seperti diabetes mellitus, hipertensi dan penyakit kardiovaskuler (Sunarti dkk, 2013).Hal ini sependapat dengan teori yang dinyatakan oleh Soegih, bahwa obesitas akan menambah beban kerja jantung dan terutama adanya penumpukan lemak dibagian sentral tubuh akan meningkatkan resiko PJK.

Terdapat adanya kaitan antara lemak dalam rongga perut dan nilai rasio lingkar pinggang pinggul dengan kadar kolesterol, artinya semakin tinggi nilai rasio lingkar pinggang pinggul atau semakin banyak timbunan lemak dirongga perut akan diikuti dengan tingginya kadar kolesterol low density lipoprotein, juga diikuti dengan meningkatnys kadar kolesterol total.(Fikri, 2009).

Hal ini didukung oleh penelitian Gotera (2009) menyatakan bahwa terdapat hubungan antara obesitas dengan penurunan kadar kolesterol HDL serta peningkatan kadar kolesterol low density lipoprotein. Dengan meningkatnya kadar kolesterol low density lipoprotein darah dan menurunnya kadar kolesterol HDL darah mempunyai pengaruh terhadap terjadinya penyakit jantung dan stroke.

\section{KESIMPULAN}

Hampir seluruh pasien yang berobat di poli jantung RSUD M. Yunus sering mengkonsumsi lemak jenuh maupun lemak tak jenuh.RLPP hampir seluruh pasien mengalami obesitas atau penumpukan lemak di perut.Hampir seluruh pasien berusia 45 tahun keatas.Sebagian besar pasien berjenis kelamin laki-laki.Tekanan darah sebagian besar pasien cenderung normal.Sebagian besar pasien memiliki kebiasaan merokok.Ada hubungan antara pola konsumsi lemak (jenuh dan tak jenuh), RLPP, jenis kelamin, dan merokok dengan pasien PJK di poli rawat jalan RSUD M. Yunus Kota Bengkulu Tahun 2017.Tidak ada hubungan antara usia dan tekanan darah dengan pasien PJK di poli rawat jalan RSUD M. Yunus Kota Bengkulu Tahun 2017.

Bagi peneliti lain hendaknya dilakukan penelitian dengan penambahan variabel lain yang menjadi faktor risiko PJK seperti aktifitas fisik dan kadar kolesterol pada pasien penyakit jantung koroner di poli rawat jalan RSUD M.Yunus Kota Bengkulu. 
Bagi rumah sakit hendaknya ahli gizi memberikan edukasi 1 bulan sekali terkait

\section{DAFTAR RUJUKAN}

Almatsier Sunita. 2010. Prinsip Dasar Ilmu Gizi. Jakarta: Gramedia Pustaka Utama.

Centers for Disease Control and Prevention (CDC).2009. Coronry Artery Disease (CAD). CDC.

USA

Avaible: http://www.cdc.gov/heartdisease/coronary_ad. htm. Tanggal12Januari 2014.

Departemen Kesehatan RI.2007. Pharmaceutical Care untuk Pasien Penyakit Jantung Koroner: Fokus Sindrom Koroner Akut. Bina Farmasi Komunitas dan Klinik Ditjen Bina Kefarmasian dan Alat Kesehatan Dep.Kes RI. Jakarta. Direktorat.

Fikri F. 2009. Bahaya Kolesterol Memahami, Mendeteksi, dan Mengontrol Kolesterol. Yogyakarta: Kata Hati.

Goetera W, Suka A, Ketut S, Anwar S, Tuty K. 2009. Hubungan Antara Obesitas Sentral dengan Adiponektin Pada Pasien Geriatri dengan Penyakit Jantung Koroner.Jurnal Penyakit Dalam, 7 (2):102-107.

Hardiansyah. 2011. Analisis Konsumsi Lemak, Gula dan Garam Penduduk Indonesia.Gizi Indonesia. 34(2):92-100.

Keteren S. 2009. Pengantar Teknologi Minyak dan Lemak Pangan.Jakarta : Penerbit Universitas Indonesia. bahan makanan yang baik dikonsumsi atau tidak untuk pasien penyakit jantung.

Muller H, Lindman AS, Brantssaeter AL, Pedersen JI. 2010. The Serum LDL/HDLCholesterol Ratio is Influenced More Favorably by Exchanging Saturated with Unsaturated Fat Than by Reducing Saturated Fat in The Diet of Women. J Nutr.

Riska DK, Hidayati SS, Fadhlah Eriza.2008. Hubungan Lingkar Pinggang dengan Kadar Trigliserida pada Pasien Rawat Jalan Dislipidemia di Puskesmas Janti Kota Malang.http://fk.ub.ac.id/articel/id/filedownloa d/gizi/DIAN\%20RISKA.pdf.

Sulastri D, Rahayuningsih S, Purwantyastuti. 2005. Pola Asupan Lemak, Serat, dan Antioksidan, Serta Hubunganya dengan Profil Lipid pada Laki-laki Etnik Minangkabau.Kedokteran Indonesia. Volume : 552.

Sunarti dan Maryanu E. 2013.Rasio Lingkar Pinggang dan Pinggul dengan Penyakit Jantung Koroner di RSUD Kabupten Sukoharjo. Buletin Penelitian Sistem Kesehatan. 16(1):73-82.

Tuminah S. 2009. Efek Asam Lemak Jenuh dan Asam Lemak Tak Jenuh "Trans" Terhadap Kesehatan.Media Penelitian dan Pengembangan Kesehatan Volume XIX tahun 2009. Suplemen II 